\title{
Policy Framework for Community and State Policing in Combating Rising Security Challenges in Nigeria
}

\author{
Ngozi Nwogwugwu, Adebusola Morenikeji Odedina \\ Babcock University, Ilishan-Remo, Nigeria
}

\begin{abstract}
Viability of decentralizing policing in Nigeria had been on the front burner of security discourse since Nigeria returned to democratic governance in 1999. Valid points had been put forward by both those in support and those in opposition. The Community Policing Department of the Nigeria Police had remained more of an administrative unit with little impact beyond the Police Community Relations Committee activities. Rising cases of herdsmen attacks of various communities, terrorist insurgency in the North-East, kidnappings across the different geo-political zones had resulted in the need to interrogate the efficacy of effective community policing and state policing as viable options to combating rising security challenges. The study adopted qualitative method, and being a library research relied entirely on secondary data. Sources of data included journals, relevant textbooks, newspapers, magazines, and materials downloaded from internet. The paper argues that the traditional security agencies had failed to effectively combat the many security challenges that Nigeria faces. The combination of the official security agencies and the military had failed to effectively combat insecurity in the country. The local vigilante groups on the other hand had made valuable inroad in curtailing some of the security challenges including terrorist insurgency as a result of their knowledge of the terrain. The paper concludes that to effectively combat the many security challenges, there is a need for new policy framework at the federal and state levels that would decentralize policing and give legal backing for collaboration between the official security agencies under the federal government and state security outfits including the vigilante.
\end{abstract}

Keywords: community policing, state policing, security challenges, policy framework, vigilante

\section{Introduction}

It is generally accepted that the principal role of government in any society is to provide security. No doubt, security is the ultimate for all times, climes, peoples, and nations and "unless one can be assured of his physical security or safety, everything else will be meaningless” (Kupoluyi \& Nwogwugwu, 2015). According to Imobighe (2003), without security, individuals within a state will find it difficult to engage in productive activities. Similarly, without security, the state is bound to experience great difficulty in harnessing its human and material resources towards meaningful development and the promotion of the general well-being of the people. The internal or domestic security of a country is very crucial for the attraction of foreign investments, as well as nation-building and national development. Foreign investors would prefer to go to investment

Ngozi Nwogwugwu, Ph.D., Senior Lecturer in the Department of Political Science \& Public Administration, Veronica Adeleke School of Social Sciences, Babcock University, Ilishan-Remo, Nigeria.

Adebusola M. Odedina, Ph.D. student in the Department of Political Science \& Public Administration, Veronica Adeleke School of Social Sciences, Babcock University, Ilishan-Remo, Nigeria. 
destinations that are regarded as secure (Kupoluyi \& Nwogwugwu, 2015).

Over the last decade, Nigeria had experienced tremendous security challenges, ranging from militancy in the South-South geo-political zone, ethnic conflicts across the different geo-political zones to terrorism and insurgency in the North-East geo-political zone of the country. The terrorist insurgency in the North-East appears to be Nigeria's worst security threat in the last few decades and had exposed some deep-seated lapses that had long existed in the governance process in the country (Nwogwugwu \& Abioye, 2015). The UNDP observes that the incidence of citizens not trusting the state to adequately perform its statutory duty is not a uniquely Nigerian problem; rather it is something that had been observed amongst several states.

The security agencies in Nigeria appear to lack the capacity to proactively pre-empt possible attacks and nip them in the bud before execution, as they are more of reactionary in their operations. There have been reported cases where terrorist and sometimes armed robbers gave notice of where they intention to attack specific locations and still succeeded in executing such attacks undeterred. The situation where security agencies only react after the terrorists or other criminals have finished unleashing mayhem across communities and local governments leaves residents of such communities petrified at the utter helplessness of the security agencies and makes them unwilling to return those communities even after the places have been reported as having been recovered from the terrorists (Kupoluyi \& Nwogwugwu, 2015). This has been the case in several communities in the North-East region of the country, where residents have refused to return to their communities for fear that the terrorists although reported to have been dislodged may still attack them in future.

Since 2015, though there has been reported improvement in the capability of the Nigerian Army to engage and checkmate the excesses of Boko Haram terrorist group, as confirmed by the report by Daily Post (2016) that seven hundred Boko Haram members surrendered while Ugwuanyi (2016) cited a US Bureau of Counterterrorism and Counter Violent Extremism (2015) that its ability for territorial control had been degraded. However, the terrorists have resorted to attacks at their targets from time to time without taking effective control of such targets. As such the number of local governments under their control in Bornu and Adamawa States has become minimal.

Historically, policing and police work did not start as a paid profession. Rather, it started as a noble, incorruptible profession with considerable responsibility and distinction (Newburn, 2004). Just as leadership mirrors the state of a given society, policing in Nigeria had always reflected the society that created it. The primary purpose of the police was to advance the economic and political agenda of the colonialist. It is historically accepted that, the police engaged in the brutal subjugation of communities and the suppression of resistance to colonial rule. Thus, the use of violence and repression from the beginning of colonial era marked a dislocation in the relationship between the police and local communities, which had characterized law enforcement practices in Nigeria ever since (Kupoluyi \& Nwogwugwu, 2015).

The Nigeria Police which is centrally controlled, has over the years metamorphosed to a state where it is allegedly characterized by various social vices such as graft, corruption, robbery, and indiscipline (Tunde-Awe, 2005). All these have posed and still pose serious security threats, resulting in loss of confidence by the citizens on the government and its security agencies. This has in turn continued to fuel agitations for the decentralization of the police for effective and efficient safeguarding of lives and property. It is view of the fore-going that the paper interrogated policy framework for community and state policing in Nigeria as mechanism for achieving effective security of lives and property in the country. In this study which is a library research, we rely on secondary qualitative data gathered from journals, relevant textbooks, newspapers, 
publications of relevant institutions charged with responsibility for security issues at international and national level, as well as relevant materials downloaded from the internet. We analyzed our data employing the interpretative analytical approach, linking the major variables of study policy framework, community and state policing and security challenges. Our study is presented under the following sub-sections: introduction, theoretical background, theoretical framework, methodology, appraisal of the debate on state policing in Nigeria, pro-community policing debate, new policy framework for security management in Nigeria, conclusion and recommendations.

\section{Theoretical Background}

\section{Policy}

Governments across the globe in modern societies have the responsibilities of ensuring that their societies are secured and that the citizenry have the enabling environment to achieve their individual and group objectives. In ensuring that the goals of the government are met, in the face of varying challenges, the government equally has to ensure that its plans and programs are not executed in a haphazard manner. As a result, the government resorts to the use of policies to give direction and focus to its actions in order to ensure that set goals and objectives are met. This has become of utmost importance as societal development thrown up in an increasing manner various security challenges which the government has to battle with, if it is to fulfill one of its key responsibilities of securing the lives of its citizenry and their property.

Policy like other concepts in the management and social sciences has been subjected to varying definitions based on the perspective of each scholar. Presthus (1975) defined policy "a definite course or method of action selected from among alternatives and in the light of given conditions to guide and usually determine present and future decisions" (p. 14). William Jenkins defines public policy as "a set of interrelated decisions taken by a political actor or group of actors, concerning the selection of goals and the means of achieving them within a specified situation where those decisions should, in principle, be within the power of those actors to achieve' (Sharma, Sadana, \& Kaur, 2012, pp. 633-634).

However, the later definition provides the emphasis that policies are usually made for specific situations or issues. The specific issue of concern for this paper is security, which is adjudged one the key responsibilities of the government of a state.

Policy is not made in a vacuum. Those who are in charge of formulating it are constantly subject to influences of various kinds. First and foremost influence on policy making is that of the environment in which the political system operates. Environment broadly comprises institutions (economic and social), history, law, ethics, philosophy, religion, education, tradition, belief, values, symbols, myths, etc., which may be described as material as well as non-material culture (Sharma, Sadana, \& Kaur, 2012, p. 640).

\section{Policing}

Analytically, policing refers to measures and actions taken by a variety of institutions and groups (both formal and informal) in society to regulate social relations and practices in order to secure the safety of members of community as well as conformity to the norms and values of society. It is, therefore, a sub-set of control processes which involves "the creation of systems of surveillance coupled with the threat of sanctions for discovered deviance, either immediately or in terms of the initiation of penal process or both” (Reiner, 2000, p. 3). Where the members of community feel insecure, or that the various mechanisms put in place lack the 
capacity to guarantee their safety, it becomes a major subject of concern for such a society. A given society must be seen as having the capacity to counter and sanction deviance of various kinds in order to avoid falling into a state of anarchy.

State agencies designated as police, as well as community groups, are involved in policing. But not all community policing groups that carry out activities aimed at safety and social order constitute police. Given the strategic importance of policing for the proper functioning of a society, no modern society can do without policing. Several scholars have made worthy contributions to the subject of policing from various perspective including Tamuno (1993; 1985; 1970), Newburn (2004), Obiekezie (1986), and Nwolise (2004). In Nigeria, policing is regarded as the responsibility of the federal government which is the reason why the policing function is officially centralized. This had resulted in various dilemmas where the state governors are regarded as Chief Security Officers of their states, while the State Commissioner of Police reports to the Inspector General of Police at Abuja, who in turn reports to the President and Commander-in-Chief. So, the state governors are nominal security chiefs without direct control of policing in their states. However, when there are major breaches of security within a particular state, the state governor is blamed for not ensuring the safety of lives and property in the state.

\section{Community Policing}

The notion of "community policing" stems from the argument that government alone cannot provide all the needed requirements of descent living and security of life and property. This calls for collaborative efforts by different communities and government or security agencies. This is borne out of the understanding that peoples' security is the best form of security and as such could complement the role of government in securing lives and property. According to Amadi (2014), community policing,

is a philosophy of policing based on the idea that-if the police and citizens in the community work together in creative ways to fight and prevent crime, then crime-related problems of the community would be solved, fear of crime would be reduced, community residents would feel safer, and the physical conditions as well as the quality of life in the community would be better. (p. 19)

According to the United States Institute of Peace (USIP), Special Report (2014) community policing is an organizational strategy or instrument that aims at promoting partnership that is based collaborative efforts between the police and the community to ensure safety and security.

The central role of community security made it to form one of the seven dimensions of human security elaborated in the 1994 Human Development Report. The emphasis is on the security that people derive from the groups they belong to, which in turn provides a cultural identity and a reassuring set of values. The UNDP broadens the perspective by including both group and personal security, focusing on ensuring that communities and their members are "free from fear". Those who live in fear cannot be said to be secured, even though there may not be evident crisis or violence in their environment.

Djudjevic-Lukic (2014, p. 2) writes that community policing consists of two complementary core components. These are community partnership and problem solving. It is therefore of utmost importance as he rightly observed that the police and the community collaborate to encourage and preserve peace and prosperity. This cannot be achieved without the establishment and maintenance of mutual trust within the community and between the police and the group. In societies such as Nigeria where the average citizen does not really trust the police, community policing becomes a major bridge that could provide the platform for building such relationship. 
Writing on the importance of community policing, Udefuna, Madu, Akalefu, and Jumare (2014, p. 262) posit that crime detection becomes easier when communities are adequately involved. This is due mainly to the fact that members of a given community could easily detect strangers and criminals among and report same to community police officers among them. In this way incidences of crime will be reduced, law and order maintained and peace achieved.

Community policing has its own challenges. First, it could be used to settle old grudges within a community as records abound of local vigilante engaging on extra judicial killing, like the Bakassi Boys experience in Aba, Abia State during the tenure of Orji Uzor Kalu as governor (1999-2007). Second, it might lead to proliferation of small and light arms and ammunition that could be deployed in intra or inter community rivalry. Third, given that they may not be adequately trained, cases of accidental discharge cannot be eliminated.

Nonetheless, these challenges are not insurmountable given that the police could regulate the firearm at the disposal of the vigilante, give them proper training, and can be remunerated adequate to sustain their loyalty while the membership of the group must be nominated from the Community Development Association or the traditional ruler. Writing on community policing in USA, Amadi (2014) emphasized the role of police partnership with citizens to ensure the achievement of safer environments. Such partnership require that police work with local community leaders, in identifying residents who could be of value in security related issues of the community for adequate training for community policing responsibilities. Furthermore, such partnerships would result in situation where

the police become a catalyst in the development of community projects such as neighborhood watch programs, neighborhood revitalization projects, and youth-oriented educational and recreational programs. Citizens on their part may become involved as volunteers, reserves, or auxillaries on an individual basis or as groups in the collaborative effort with the police. (Cordner, 1995, p. 505 cited in Amadi 2014, p. 22)

The Committee of the American Institute of Criminal Law and Criminology provides very clear distinction between vigilante group, even when it is under the control of the state, and the formal police system. According to the institution, state police is as a,

specially organized and highly trained body, acting under state rather than local authority, and constantly employed in the prevention of crime, the apprehension of criminals, and the protection of life and property generally throughout the state and especially in the rural and sparsely settled districts. (Corcoran, 1924, p. 544)

State police became prominent due to a number of reasons going by the experience of the United States of America, as stated by Corcoran (1924):

(1) The movement responds primarily to the increasing consciousness on the part of dwellers in rural and suburban districts of a need for a greater degree of police protection. The coming of the automobile and improved highways has widened the range of crime and rendered its control more difficult.

(2) Local sheriffs and constables are not adequate or especially fitted for this work.

(3) State militia is a clumsy and extremely expensive agency and is not trained for police duty. It is designed primarily as a supplement to the standing army for national defence.

(4) It is a movement toward centralization of government for the purpose of economy and efficiency. (p. 544)

The implication is that in the development of a nation, certain security situations may necessitate the 
review of the existing security system with a view to adopting new one that would be more functional and able to adequately secure the society.

\section{Theoretical Framework}

In interrogating the variables of this study, we adopt the social conflict theory as the theoretical construct of this paper.

\section{Social Conflict Theory}

Social conflict perspective in social theory postulates that society is divided into groups and classes with common interests in some areas and conflicting interests in many fundamental areas, including the organization, mobilization and distribution of economic and socio-political resources within a given society. Social conflict theory proposes that conflict within and between groups in a society can hinder peaceful co-existence amongst them and further hinder efforts as achieving progressive development of such society. When there are clashes of values and interests, as well as tension between what exists and what various groups expect, the conflict between "vested interest groups" or "special interests" may result in emergence of new groups demanding their share of power, wealth, and status (Coser, 1957).

Following the proposition of Coser (1957), it has been argued that the underlying motive for the establishment of the police in any given society will determine the nature of its relations with the different strata of the society and the perception that they have of it. In this light, in societies like Nigeria where "the police were not created to serve the entire 'society' or the 'people' but to serve some parts of society and some people at the expense of others” (Institute for the Study of Labor and Economic Crises (ISLEC), 1982, p. 12), there is the tendency that the police would exhibit the attributes of domination and suppression of sections of the population.

The variation in attitudes towards the police reflects the differential services rendered by the police to different segments of society. Police roles vary across societies with different political and economic organizations. For example it has been argued that in capitalist societies: The main function of the police has been to protect the property and well-being of those who benefit most from an economy based on the extraction of private profit. The police were created primarily in response to rioting and disorder directed against oppressive working and living conditions (ISLEC, 1982).

According to Bowden (1978, p. 19), the roles of police include the repression of the poor and powerless in order to protect the interests of the rulers. The police roles, therefore, include standing as a "buffer between elite and masses". Brodgen (1989, p. 203) puts this view more forcefully, stating that "Police forces are structured, organizationally and ideologically to act against the marginal strata”. This explains why the police in Nigeria respond faster and show a high degree of efficiency, when the interests of the federal government and its officials are affected, or where the rich who are at the corridors of power are affected. Pecuniary benefits are expected to follow such speedy responses, as against situations where people of the lower cadre or those who have no direct access to government have their right infringed upon or crimes committed against them. The Nigeria Police have sometimes been reported to provide excuse to the citizens who come to report cases that they are incapacitated from immediate response to emergency because of lack of fuel for the official vehicle.

The existence of this structural defect, which is traceable to the motive for the establishment of the police, 
would not have the capacity to effectively protect the ordinary citizens in the country. This brings to the fore the need for the adoption of a new mechanism that would ensure that the interests of the ordinary citizens who comprise the vast majority of the populace are adequately catered for in terms of securing lives and property in the country.

\section{Appraisal of the Debate on State Policing in Nigeria}

Nigeria over the years has been experiencing increasing rate of insecurity and other social malaise in spite various efforts by different governments. The reality is that the federally government controlled police seem to lack the ability to adequately secure the entire country effectively by countering insecurity plaguing different states in the country. This is complicated by the fact that the state governors seem powerless in exercising their constitutionally roles as the chief security officers of their states, as they have no control over the police. As a result, there have been arguments from various quarters that the only solution to the security threat of Nigeria is to embrace the federating principle of state policing.

Would the police be adopted by state officials to defend their criminal activities, as insinuated by the antagonists of state police? Or will state police serve as an antidote to the security challenges being experienced by the country as anticipated by the protagonists of state police? Therefore, it is pertinent to critically understand the two points of views for better analysis.

The strongest argument in favor of the establishment of a state police is that it accords with the principle of federalism on which Nigeria styles its constitution. As a federal state, the power of the Federal Republic of Nigeria is divided between the central government called the federal government and the 36 states of the federation in Section 2 subsections 2 of 1999 Constitution. Several scholars have put forward arguments on the need for the state to be charged with the responsibilities for policing their territories since the governors are recognized as the chief security officers of their state (Onwuzuligbo, 2012). State policing is operational in other federal states such as United States of America. Some have argued that the development of technological capabilities that have resulted in need for more proactive action at the local levels encourages the need for state policing (Ehindero, 2012). Others argue that the centralized police system lacks the capacity to tackle security challenges proactively (Adedeji, 2012).

Another school of thought argues against state police, citing the fact that Nigeria is not ripe for such an experiment. They refer to the various abuses of militia groups and some state vigilante services by the state government in which such groups are deployed for fighting political enemies as a major reason why state policing should not be approved in Nigeria (James, 2011). It is also further argued that given the inability of the states to mobilize resources for capital development, the enormous resources required for security management would be too much for states to mobilize (Adetumbi, 2012). However, the argument can be faulted on the basis of the enormous success that has been achieved by Lagos State government with its Security Trust Fund through which it has been able to mobilize resources from the private sector organizations to finance security agencies in the state. It shows that with proper planning and collaborative efforts with the private sector, the state governments can actually fund the security operations of a state police, if they are given the opportunity through the enabling law.

\section{Pro-community Policing Debate}

The centralized system of managing the security system in Nigeria has failed to curb security challenges in 
Nigeria, with the worst exposure being the sacking of communities in the North East, by Boko haram terrorist group with the security agencies seemingly helpless to curtail their forays for some years. The factors that were identified and factors that facilitated the overrunning of the communities included bad governance, corruption by public officials in the face high level of poverty among the populace, inadequate equipment of the security agencies leading to lack of capacity to effectively combat security challenges, and lack of security consciousness by the citizens.

Community policing is a paradigm shift that seeks to focus on constructive engagement with people who are the end users of the police service and re-negotiate the contract between the people and the police thereby making the community co-producers of justice and a quality police service (Okeshola \& Mudiare, 2013, p. 134). According to Ikuteyijo (2009), community policing entails community partnership in creating a safe and secure environment for all. It is policing whereby the people take active part in their own affairs. With community policing, the police are not seen as a stranger whose presence stands for danger and imminent hazard, but as partners in development. This brings about residents ownership of the strategies adopted in securing their environment, since they are involved in the decision making process including the design of the appropriate techniques and tactics to be adopted.

Obeagu (2014) writes that community policing groups, known in some quarters as vigilante or neighborhood watch, have excelled since the formal inauguration of the system in 2004 in specific areas such as protection of neighborhoods against armed robbery. Although, he identified some abuses in terms of extra-judicial punishment of apprehended criminals, with proper grooming the system could be more useful to the society given the trust that the members enjoy among the residents.

In highlighting the difference between vigilante services and neighborhood watch, Okeke (2013) writes that community policing encourages the use of neighborhood watch which is an organized group of citizens devoted to crime and vandalism prevention within a neighborhood and is different from Vigilante services. Vigilantes engage in extra-judicial punishment of apprehended criminals whereas neighborhood watch hands over apprehended criminals to the police to face the law and not execute punishment by themselves. Adoption of nationally approved policy framework that incorporates Nigeria Police, state policing and community policing will result in complete elimination of the many incidences of jungle justice or extra-judicial killings experienced in Nigeria as a result of the activities of some vigilante groups that take the law into their hands.

The non-involvement of communities in their security is a lacuna in the present security system operational in the country, which is a very major challenge. The fact that the security agencies do not have very close affinity with the communities created a situation where they were not able to tap into local resources in the process of intelligence gathering. The security agencies are too far from the people to be able to be seen as part of the community, to be seen as partners with the local communities to work for the good of the communities. There was equally lack of trust in the security agencies as the people see them as collaborators with the corrupt politicians, unworthy of being depended upon to protect the people.

The adoption of a collaborative mechanism between the police and various neighborhood watch groups has helped in curtailing armed robbery attacks in some areas in the country. Adoption of a new security structure which is more robust and involving the communities through the community development associations (CDAs) and the vigilante groups becomes the viable option for effective community policing.

Community policing would make policing closer to the people, and a massive re-orientation of the citizenry on techniques of security consciousness and need to always communicate with the community 
policing agencies of suspected security threats would go a long in curbing possible threats to security in various societies. Involvement of community development associations in local security would create community buy-in, and forestall any efforts to usurp the community policing agencies as tools of oppression by some disgruntled rulers/elements.

\section{New Policy Framework for Security Management in Nigeria}

As stated by Guy Peters, "the social and economic systems of a country place boundaries on the actions of a government...By defining what in government is good and bad, the culture may virtually mandate some actions and prohibit others" (Sharma, Sadana, \& Kaur, 2012, p. 640). This is of relevance in the present context as the culture of the Nigerian society which believes in the spirit of brotherliness may not support the total use of force on those with aberrant behaviour or who engage in activities that threaten the security of the state as some members see them as their sons and daughters and would view some actions as being too high-handed, whereas such actions may be acceptable in some other societies as they are viewed in such societies as enemies of the state.

In undertaking the investigation of the most appropriate policy framework for security management in Nigeria, it is not enough to employ only the cost benefit analysis of the policy alternative. There is need to equally engage in the social impact and environmental impact assessment of the various policy options/alternatives (Eneanya, 2013, p. 17). According to Finsterbusch and Motz (1980), considering the social and environmental impact assessment would require the measurement of the range of impact that the policy would have on the people, various groups, organizations, and the society as a whole. This is because, security policies have impact on all sectors of the society directly or indirectly and the nature of the society would determine the success of such policies as well.

Since the current centralized system of security management in Nigeria has failed to effectively combat security challenges across the length and breathe of the country, there is need for massive reform of the security sector to make the sector effective. This will involve the development of a new security framework that will proactively combat all forms of threat to security at local, state and national levels of the country. Such a framework would involve the devolution of powers from the centre to component units in line with Nigeria's federal structure. Security at the state level should be controlled completely by the state governors, while the federal security apparatus will play complimentary role, especially where inter-state crimes are involved (Nwogwugwu \& Abioye, 2015).

The envisaged new security framework at the state level will involve collaboration and building of synergy among the state police command, the state operations of the Department of State Services, state operations of NSCDC, vigilante/neighborhood watch, private security or guard companies, relevant security related Ministries, Departments and Agencies (MDAs) of government and civil society organizations (CSOs). Such collaboration would include sharing of relevant intelligence information amongst the organizations and agencies thereby building a synergy that would be difficult to beat by any gang, sect or group (Nwogwugwu \& Abioye, 2015).

The various state governors controlling the state security agencies and organizations within their domain would ensure that there is quicker intervention when there are any threats to security or breach of security, rather than the current dispensation where they have to get approval from Abuja before any meaningful action would be undertaken. It is only when the security challenge is of a national magnitude or has external 
implications that the federal security operatives would be mobilized.

\section{Conclusion and Recommendations}

Nigeria's current centralized security management system, which has been based on the traditional security framework, has over the years failed to proactively combat security threats including the many ethno-religious crises, militancy, and terrorist insurgency, amongst others. Valuable time has been lost as the security agencies look up to their high command for approval before they can react to threats. The implication is that the government has not been responsive to the needs of the citizens in terms security provision even though it is recognized that security is at the pinnacle of the duties of any government.

Many countries of the world are developing more dynamic approaches to combating security threats especially in the post September 11 era. Some of the strategies adopted by these countries have included granting of greater responsibility to emergent non-military security related Ministries, Departments and Agencies (MDAs) with a view to facilitating greater intelligence gathering so as to proactively combat the threats to security before they become prominent.

In light of the fact that other federal states such as USA, whose federal system Nigeria claims to be copying, operate a decentralized security system which has been effective to a great extent, we recommend decentralization of the security sector in order to make the sector responsive to the needs of the citizenry. State Police should be constitutionally approved within the confines of a new security framework that is based on collaboration among agencies. Community policing which should be part of the state police system should be given force of law, and the citizenry made to become active stakeholders in the security system able to provide intelligence information that would proactively curtail threats to security.

\section{References}

Adedeji, O. A. (2012). State police in Nigeria: Issues and challenges. Retrieved from http://ssrn.com

Adetumbi, O. (August 19, 2012). If we have courts at state levels...Why not state police? Nigerian compass. Retrieved from http://www.compassnespaper.org

Ajayi, F., \& Nwogwugwu, N. (July 2015). Militancy, domestic cum international terrorism: Interrogating the effectiveness of Nigeria's national security and strategic planning. The International Journal of Science \& Technoledge, 3(7), 202-209.

Alemika, E. E. O., \& Chukwuma, I. C. (2000). Police-Community violence. Lagos: Centre for Law Enforcement Education (CLEEN). Retrieved from http://www.cleen.org/police-violence.pdf

Aleyomi, M. B. (2012). Ethno-religious crisis as a threat to the stability of Nigeria's federalism. Journal of Sustainable Development in Africa, 14(3), 127-140.

Amadi, E. N. (January 2014). A qualitative analysis of community policing in the United States. American International Journal of Contemporary Research, 4(1), 119-126.

Bowden, T. (1978). Beyond the limits of law. Harmondsworth: Penguin Books Ltd.

Brodgen, M. (1982). The police: Autonomy and consent. London: Academic Press.

Brokensha, D., \& Hodge, P. (1969). Community development: An interpretation. San Francisco: Chandler Publishing Company.

Bryson, L., \& Mowbay, M. (1981). Community: The spray-on solution. Australian Journal of Social Sciences, 15(4), $255-267$.

Bureau of Justice Assistance. (1994). Understanding community policing: A framework for action. Retrieved from https://www.ncjrs.gov/pdffiles/commp.pdf

Cordner, G. W., Craig B. F., \& Wexler, C. (1991). Research, planning, and implementation. In W. A. Geller (Ed.), Local government police management (3rd ed.) (pp. 346-347). Washington, D. C.: International City Management Association.

Corcoran, M. M. (1924). State police in the United States. Journal of Criminal Law and Criminology, 14(4), 544-546.

Coser, L. A. (Sept. 1957). Social conflict and the theory of social change. The British Journal of Sociology, 8(3), $197-207$. Retrieved from http://www.jstor.org/stable/586859 
Djudjevic-Lukic, S. (2014). Community policing and community security: Theory and practice in Timor-Leste. JSRP Paper 16. Belgrade: Public Policy Research Centre.

Ehindero, S. (February 9, 2012). Which way forward for the Nigeria police: Federal or state police? The Vanguard.

Eneanya, A. N. (2013). Policy research, analysis and public policy making. Ibadan: Ibadan University Press.

Falola, T. (1998). Violence in Nigeria: The crisis of religious politics and secular ideologies. New York: University of Rochester Press.

Finsterbusch, K., \& Motz, A. B. (1980). Social research for policy. USA: Wadsworth Pub. Co.

Gourley, S. M. (Summer 2012). Linkages between Boko Haram and al Qaeda: A potential deadly synergy. Global Security Studies, 3(3), 1-14.

Hubert, D. (2001). Small arms demand reduction and human security. Ploughshares Briefing.

Imobighe, T. (1998). The management of national security. Inaugural Lecture. Ekpoma: Edo State University.

Imobighe, T. A. (2003). Civil society and ethnic conflict management in Nigeria. Abuja: Spectrum Books Nigeria Ltd.

Ikuteyijo, L. (2009). The challenges of community policing in Nigeria. International Journal of Police Science and Management, 11(3), 285-293.

Institute for the Study of Labor and Economic Crises (ISLEC). (1982). The iron fist and the velvet glove: An analysis of the US Police. San Francisco, CA: Crime and Social Justice Associates.

James, S. (September 24, 2011). IGP disbands dreaded Bayelsa security outfit. This Day.

Jonathan, G. A. (December 6, 2011). Conditions not yet right for state police in Nigeria, Abuja. Nigeria Village Square.

Kupoluyi, A. K., \& Nwogwugwu, N. (May 2015). Interrogating the desirability of state policing in Nigeria. IOSR Journal of Humanities and Social Sciences (IOSR-JHSS), 20(5), Ver. IV, 1-7. doi:10.9790/0837-20540107. Retrieved from iosrjournals.org/iosr-jhss/papers/Vol20-issue5/...4/A020540107.pdf

Lemanski, C. (2012). Every human (in) security: Rescaling for the southern city. Security Dialogue, 43(1), 61-78.

Newburn, T. (Ed.). (2004). Handbook of policing. United Kingdom: Willan Publishing.

Niven, C. R. (1958). How Nigeria is governed. London: Longmans, Green and Co.

Nwogwugwu, N., \& Abioye, O. O. (July 2015). Responsive governance and decentralization of the security sector in Nigeria. IOSR Journal of Humanities and Social Science (IOSR-JHSS), 20(7), Ver. III, 35-41.

Nwolise, O. B. C. (2004). The Nigeria police in international peace-keeping under the United Nations. Ibadan: Spectrum Books Limited.

Nwolise, O. B. C. (2009). Peace and security. In I. Albert (Ed.), Praxis of political concepts and cliches in Nigeria's fourth republic (pp. 245-278). Ibadan: Bookcraft.

Nwolise, O. B. C. (2010). Security in the federal government's agenda. In M. D. Yusuf (Ed.), The military, the media and Nigeria's national security (pp. 153-175). Ibadan: Gold Press Ltd.

Nwolise, O. B. C. (2012). Oracle on state police discourse in Nigeria: A citizen’s perspective. Paper Presented at NISER Seminar Series.

Obeagu, C. C. (2014). Community policing in Nigeria: Issue and challenges. World Journal of Management and Behavioral Studies, 2(3), 58-68.

Obiekezie, I. C. (1986). The police and instability in Nigeria (M.Sc. Thesis, Department of Political Science, University of Ibadan).

Okeke, V. O. S. (2013). Community policing, vigilante security apparatus and security challenges in Nigeria: A lesson from Britain and Igbo traditional society of Nigeria. British Journal of Arts and Social Sciences, 14(II), 306-323. Retrieved from http://www.bjournal.co.uk/BJASS.aspx

Okeshola, F. B., \& Mudiare, P. E. U. (July 2013). Community policing in Nigeria: Challenges and prospects. American International Journal of Contemporary Research, 3(7), 134-138.

Okoli, A. C., \& Ioryter, P. (2014). Terrorism and humanitarian crises in Nigeria: Insights from Boko Haram insurgency. Global Journal of Human Social Sciences, 1(1), 39-49.

Onwuzuligbo, D. (August 13, 2012). Insecurity: Is state police the panacea? Nigerian Pilot. Retrieved from http://www.nigerianpilot.com/index.php/crime

Reiner, R. (2000). The politics of the police. Oxford: Oxford University Press.

Roberg, R., Crank, J., \& Kuykendall, J. (Eds.). (2000). Police and society. Los Angeles, CA: Roxbury Publishing Company.

Rotimi, K. (2001). The police in a federal state: The Nigerian experience. Ibadan: College Press Limited. 
Sharma, M. P., Sadana, B. L., \& Kaur, H. (2012). Public administration in theory and practice (48th ed.). Allahabad, India: Kitab Mihal Agencies.

Tamuno, T. N., Bashir, I. L., Alemika, E. E. O., \& Akano, A. O. (Eds.). (1993). Policing Nigeria: Past, present and future. Lagos: Malthouse Press.

Tamuno, T. (1985). The responsibility for crime control in Nigeria (Distinguished lecture series). Ibadan: Nigerian Institute for Social and Economic Research.

Tamuno, T. N. (1970). The police in modern Nigeria: 1861-1965. Ibadan: Ibadan University Press.

Tunde-Awe, B. M. (2005). Proposing a curriculum for the Nigerian police force. Ilorin Journal of Education, 4, 23-30.

Udefuna, P. N., Madu, M. E., Akalefu, C., \& Jumare, F. (February 2014). Effective community policing: A panacea to inefficiency and impunity in Nigerian police. International Journal of Humanities and Social Science, 4(4), $260-267$. Retrieved from http://www.ijhssnet.com/journals/Vol_4_No_4_Special_Issue_February_2014/30.pdf

Ugwuanyi, Y. (June 12, 2016). Boko Haram’s ability for territorial control degraded. Daily Post.

United States Institute of Peace Special Report (2014). What is behind latest Nigeria attacks by Boko Haram? Retrieved from https://www.usip.org/blog/2014/02/whats-behind-latest-nigeria-attacks-boko-haram 